\title{
Research and Application of the Flip Classroom for English Majors in Vocational \& Technical College Against the Background of Digital Educational Technology
}

\author{
Dong $\mathrm{Wu}$ \\ Foreign Language Department \\ Sichuan Vocational and Technical College \\ Suining, Sichuan, 629000, China \\ E-mail:38326495@qq.com
}

\begin{abstract}
With the progress of information technology, digital education is fast developing. The close combination of English teaching and micro-lessons can provide students with new and efficient classroom models. Therefore, the application of micro-lessons in Vocational and Technical College English can help improve teaching efficiency. This article analyzes the application and existing problems of micro-lessons in the flip classroom of Vocational and Technical College English in the context of current digital education technology. It hopes to provide references for improving the teaching efficiency as well as learning efficiency of higher vocational English.
\end{abstract}

Keywords: Digital education technology background; Vocational and technical English flip classroom; Micro-lessons; Research and application: Problems

\section{INTRODUCTION}

A flip classroom is able to reverse the traditional teaching model of the two aspects of knowledge transfer along with knowledge absorption. This is achieved when the process of knowledge is transferred from the classroom to after classroom or home; while at the same time, reversing the process of absorbing knowledge from after classroom or home to classroom. Teaching videos are the main mode of learning first and ten teaching. It helps to promote a positive classroom atmosphere, stimulate students learning initiative and expand teaching content with the times. It needs the school or educational institution to provide digital education technology as well as equipment protection.

\section{ADVANTAGES AND DISADVANTAGES OF TEACHING IN THE BACKGROUND OF DIGITAL EDUCATION TECHNOLOGY}

The development of digital education has brought new reforms in teaching. A classroom is no longer restricted by space and time restraints. Teachers and students alike, are now able to communicate more quickly and efficiently on the Internet. This also means that students who encounter problems can be assisted in a much more timely manner. This can greatly improve students' learning efficiency. However, this method has a certain degree of an illusory nature. If students use the Internet learning for extended periods of time, they will feel uncomfortable and could possibly find themselves dealing with psychological loneliness among other things. At this time, students need to go back to the classroom for face to face communication with their teacher. Firstly, this means together, students and teachers can work through problems that cannot be solved online. Secondly, communication between classmates and teachers is conducive to the elimination of ill feeling and breakthroughs in learning.

\section{THE APPLICATION OF MICRO-LESSONS IN A FLIPPING CLASSROOM}

Micro-lessons are new form of online education. Video is the main carrier. Through video, certain knowledge points are displayed and explained. It is characterized by strong pertinence, good interaction, wide application, and is loved by teachers and students alike. Therefore, more and more physical classrooms and online classrooms use micro-lessons to teach under the flipping classroom teaching mode. Micro-lessons have also become the key part of the flipping classroom. Teachers use the knowledge of lessons learned in the form of lectures or slides in micro-lessons before class to apply their knowledge to solve problems.

\section{THE ADVANTAGE OF MICRO-CLASSES}

First, the guidance of differentiation is realized in micro-classes in that knowledge is passed on using multimedia. After viewing a video, which can be done after class, students can watch it whenever they feel necessary. They are able to pause and replay the video at any time during the process of viewing until they fully understand what is being taught, they are then much more able to apply this knowledge fully.

The feature of micro-classes is that they enable students at different levels to complete their learning progress according to their own ability, thus ensuring that they have a thorough understanding of what they have learned. For example, students with strong receptive abilities can progress quickly, without waiting for other students who are not at the same level. At the same time, students who are less receptive can slow down their learning process and no longer be anxious that they are not keeping up with their peers. Although the problem of differential tutoring for students cannot be completely solved by micro-classes, it does provide a great support and solution for this issue. In a traditional teaching mode, teachers bear the double limitation and pressure of the number of students and the time of classes. The application of micro-classes relieves this pressure of classroom teaching and realizes the differential guidance to students. 
Secondly, micro-classes improve the students' enthusiasm for learning. Using a micro-class to teach English courses in higher Vocational Colleges can greatly improve the students' enthusiasm for learning and English learning efficiency and achievement. After the teachers apply the micro-class to the flipping class, a lot of time is saved in each class. This means that the teacher has more time in each class to test the students' degree of understanding and mastery of what they have been learning as well as providing specific solutions and individual guidance to the students.

This way of teaching provides more effective use of time for communication and the opportunity for teachers and students to talk about any problems they may be encountering with this study and general life situation. The application of the micro-classes not only enhances the communication between the students and teachers but also increases the communication between students and their peers. These students are better able to communicate with each other about the learning situation and the problems they may be facing during within their learning. This also helps them to depend on each other and work more closely together alongside improving and developing their learning. Teachers can group students in the class to work together on team laboratory exercises, field surveys, research and group learning activities. The application of the micro-class in the flipping class turns the students from sitting in the classroom passively waiting for the teacher encourage and engage them. Micro-classes have greatly mobilized the students' enthusiasm for learning and improved their problem solving abilities. This makes it less likely that problems will develop.

Thirdly, micro-classes realize a teacher's self-development

The application of micro-classes in a flipping classroom is not only beneficial to teaching, but also to a teacher's self-improvement and development. English as a language changes constantly and English teachers need to add new knowledge continuously in order to better carry out their teaching work. First, micro-classes can help teachers improve their professional abilities. This is true due to the process of designing and developing micro-classes. Meaning teachers can find their own shortcomings while at the same time, analyze and solve problems. This problem finding, problem solving process can effectively promote teachers in keeping up a professional standard. Secondly, micro-classes can train and improve a teacher's ability to apply information technology. The manufacturing process of micro-classes involves many techniques: video shooting, editing, networks and so on. If a teacher wants to make a good micro-class video, he must learn to use these techniques. Through the application of these technologies, a teachers science and information technology has been improved and integrated, also strengthening comprehensive ability.

Finally, the process of using micro-classes realizes resource sharing, so teachers strengthen communication and learning. Teachers can also watch and share the micro-curriculum made by many Vocational Colleges. This can be done at home and abroad via the internet enabling teachers to grow and expand professionally.

\section{V.THE CURRENT SITUATION OF THE CONSTRUCTION OF MICRO-CLASS RESOURCES WEBSITE}

In recent years, a lot of micro-class resource websites and software has emerged and received positive responses. In these micro-class resource websites, the most influential in foreign countries is Khan College. China's most influential website is China Micro-class Network, which has tens of thousands of classes pertaining to micro-classes. In addition to the content of the micro-class themselves, teachers can also learn new skills on video recording, audio recording and video editing on these sites. A useful script can make the manufacturing process much simpler. You can also record audio, video with script and the end product will be saved and share to students after editing.

\section{THE APPLICATION OF THE FLIPPING CLASSROOM IN ENGLISH MAJORS IN HIGHER VOCATIONAL COLLEGES}

\section{A. The Teaching Feature of a Flipping Classroom in English Majors in Higher Vocational Colleges}

Under the background of digital education technology, the application of flipping classrooms for English majors in higher Vocational Colleges is innovative and reformational in comparison to the traditional teaching model. First, the role between teachers and students has changed radically in such a teaching model. During the flipping class, the teacher serves as a helper instead of playing the role of leader. Students learn to study, explore and actively seek answers rather than learning passively.

Secondly, the teaching procedure has been disrupted. In the environment of the flipping class within higher Vocation education, the teaching time has been shortened dramatically. The flipping class transforms the traditional role where teachers put all their attention into instilling knowledge on students. On the other hand, a flipping class attaches great importance to giving sufficient time to students who can learn by themselves. Students can solve their puzzle by asking for help from their teacher, they can practice oral English listening and discuss with others before being instructed by the teacher.

In a word, students are more prone to learn and study English much more actively which develops their ability tremendously.

Thirdly, a flipping classroom in English majors in higher Vocational Colleges has changed the resources of the English teaching. Generally a textbook is the main resources used in traditional teaching whereas a flipping class teaching resource is mainly video. Students learn according the video provided by their teacher. At the same time, notes must be made preparing for the quiz. Last but not least, traditional teaching models are based on classes, but in a flipping class, teachers instruct students personally on the basis of each student's characteristics, meaning every student's potential can be developed and English level enhanced.

\section{B. Problems Existing in a Flipping Class in English}




\section{Majors in Higher Vocational Colleges}

First of all, the application of flipping classes in English majors in higher Vocational Colleges needs advanced technical equipment to display information and knowledge points. To achieve this sufficient funding is an important element for well-equipped multimedia classrooms. Due to the shortage of funds, most colleges or universities in our country cannot provide the hardware and software systems needed. Some colleges or universities have multimedia classrooms but there are always new technical problems which are due to the lack of timely updates.

Second, the main body of a flipping class is students. This is to say that the teachers' supervisory role in traditional teaching is weakened, and the students' autonomy can't be guaranteed. This requires teachers not only to provide students with video materials but to also find ways of supervising students and ensure that they are watching and learning each micro-lesson in a positive way.

\section{Matters Needing Attention in the Realization of English Flipping Classrooms in Higher Vocational Colleges}

1) The application of a flipping classroom in higher vocational English teaching is closely combined with English teaching objectives. No matter what teaching method teachers add into the flipping classroom, its principle must combine with the English teaching goal. This is due to the fact that the teaching goal is the basis of English flipping classroom content in higher vocational education. In the application of a flipping classroom, the original classroom teaching time is used in micro-class teaching, but in the classroom, the discussion and research of knowledge points are mainly carried out and classroom exploration and research should also be based on the teaching objectives for the class.

2) The need of flipping classrooms is to cover the whole network. College students live in student dormitories. A flipping classroom requires students to watch and learn a micro-lesson video after class. This requires schools to figure out the problem of network coverage as watching a video requires a smooth and efficient network.

3) Teachers should use a variety of micro-class methods to attract students' interest. Any kind of teaching mode, even if new, after long-term use, will make students feel bored and stale. This requires the teacher to regularly change the content and mode of the video when creating a video for the flipping classroom. For example, the teacher can set interesting tasks for learners to complete.

4) Establish reward and punishment mechanism to cultivate students' self-management and restraint ability. In order to ensure the students initiative in learning and the effects of the flipping classroom, it is necessary to have reasonable reward and punishment mechanisms alongside good management measures. Only in this way can we better supervise and manage students autonomous learning to ensure that classroom interaction can proceed smoothly and achieve the desired results from English in a flipped classroom in higher vocational colleges.

5) The application of the English flipping classroom in higher vocational colleges should be based on the development of students. The main learning method of English flipping classrooms in higher Vocation Colleges in the micro-class video. Students can arrange their learning content and learning progress according to their actual situation during the course of the learning process. Students can complete their tasks in a relaxed learning environment. During the learning process, students can communicate with teachers and students through chat software as soon as they encounter any problems. Therefore, teachers should work out the content and progress of micro-courses according to the students' actual developmental needs and ability.

6) The application of English flipping classrooms in higher Vocational Colleges should pay special attention to improving the ability of English listening and speaking in students. As a language, the fundamental purpose the learning it is to use it to express and communicate with other using the English language. Therefore, teachers should pay special attention to students English communication ability in the flipping classroom teaching of higher vocational English as well as giving students adequate time to practice English listening and speaking. It can assist students with face to face guidance in pronunciation and intonation, this improving students' enthusiasm for learning English. The correct guidance of teachers can not only improve a student's English listening and speaking ability, but also improve the subjective initiative of students learning.

\section{CONCLUSION}

To sum up, under the background of digital education technology, there are some problems in the application of an English flipping classroom in higher vocational education and it is not enough to be popularized. But the benefits of this mode, both for teachers and students alike, are significant. The school should try its best to provide the necessary software and hardware facilities required for this teaching mode. Teachers need to take the development of students as the starting point and commit to the management of rewards and punishments alongside students autonomous learning abilities. This will ensure that students and teachers gain the very best from this method of learning.

\section{REFERENCES}

[1] Bishop, J. L., \& Verleger, M. A. (2013). The flipped classroom: A survey of the research. In Proceedings of 120th ASEE Annual Conference Proceedings. Atlanta, GA.

[2] Copley, J. (2007). Audio and video podcasts of lectures for campus-based students: production and evaluation of student use. Innovations in Education and Teaching International, 44(4), 387-399.

[3] Strayer, J. F. (2012). How learning in an inverted classroom influences cooperation, innovation and task orientation. Learning Environment Research, 15(2), 171-193.

[4] Bergmann J, Sams A (2012) Flip your classroom: reach every student in every class every day. International society for technology in education

[5] Schmidt SMP, Ralph DL (2014) The flipped classroom: a twist on teaching. Paper presented at the clute institute international academic conference, San Antonio, Texas, USA 